 \\ 反笣動物における猝内分泌に関する最近の研究
}

佐々木康之

東北大学農学部，仙台市 980

\section{Recent Progress in Researches on Endocrine Pancreas in Ruminants}

\author{
Yasuyuki SASAKI \\ Faculty of Agricuture, Tohoku University, Sendai-shi 980
}

REID ${ }^{11} 1951$ 年に，インスリン投与めえ羊の血桾低 下が非反得動物に比較して䌅徐であり，非反贸動物では インスリンショックを招くほどの低血糖にめん羊がよく 耐えること至報告し，反燿動物のインスリン感受性が非

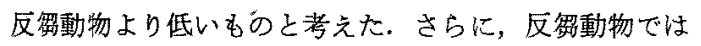
消化管からのブドウ桾吸收が認められず，血䌅値の低い ことるあって，代謝調節の中心に位置するはずのインス リンの反徨動物に扑ける役割が再確諗されるまで，その 重要性認識の点で多少の混乱があった.

非反虫動物ですでに確認されているように，反第動物 でもインスリンが物質代謝調節のか㞧めとなっているこ とに疑いはない，例えば，膵摘出あるいはフロキサン投 与でインスリン欠乏状態に陥ると，反罚動物でもブドウ 糖, 酰酸の利用が低下するとともに脂肪酸動員が活潑に なるなど，非反殿動物で認められる様な代謝異常が生ず $ろ^{2,3)}$.ま九，脂肪組織におけるプドウ糖，酶酸利用にお

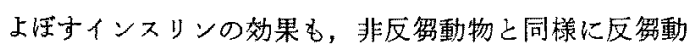
物でも認められる

YALOW and BerSON7により開発されたインスリンラ ジオイムノフッセイが普及するようになって，反鲑動物 分野に括ける膵内分泌研究も，1960年代に入って活潑に 行われるようになった，以下に，非反忽動物との対比を 交えながら，反得動物膵内分泌研究の現沉を俯橄した w.

\section{インスリン分泌の日内変動とその調節}

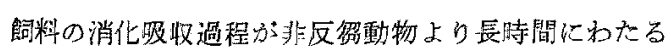

反䌓動物では，第一胃から下部消化管への内容物移動が 連続的に行われる，摸食後の栄養索吸収の高主りも持続 的である. 反忽動物のインスリンおよびグルカゴンの日 内変動はこのような消化吸收過程と密接に関連し, 変動 の振幅は摄食時に顕著である. 成長ホルモン分泌の变動 も掑食時に著しい8-11). めえ羊およびうしで，掑食後に 血永インスリン漲度が上昇し ${ }^{10,12-18}$ ，飼料の種類によっ てはヒトの食事後のインスリン濃度上昇上同程度に早い こともある. 一般に摄食 2〜4 時間後にインスリンレべ ルが上昇するが掑食速度が早ければ 4 時間以内に最高値 飞達与る ${ }^{9}$. 哺乳仔めん羊の血䈨インスリンおよびブド ウ糖源度の上界は成めん羊よりも，むしろヒトで見られ る変化に近い10)。一日一回の飼料給与をうけているめん 羊で, 12 時間後に追給飼するとき，インスリンレベルは

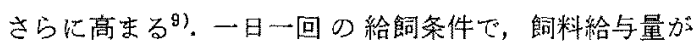
多くなるにつれて掑食後の高インスリンレバルの持続時 間が延長する゙、飼料の種類によって掑食にともなうイ ンスリン分泌も变化し, 乾草で弱く, 濃厚飼料で高い

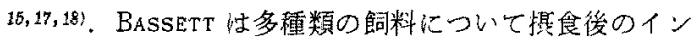
スリンレベル楚調查し，可消化有機物含量の高いほど提 食後のインスリン濃度が高まるとしている8)、末処理力 ゼインよりもホルマリン処理カゼイン添加飼料で，掑食

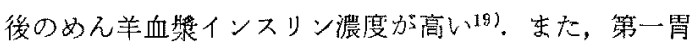
内酸醉をらけ奴ように処理されたタンバク定添加した飼 料でも，未処理のものより掑食後の血漿インスりン漫度 上昇が著しい20)．このことは，第四胃以下の消化管への 飼料タンパクの流入が，インスリン分泌剌激要因となる 
ことを示唆している.

掑食後以みとめられるインスリン分泌充進は基本的に 非反すう動物でみとめられるのと同样の現象であるが， インスリン分泌を克進させる要因は非反劦動物と巽な

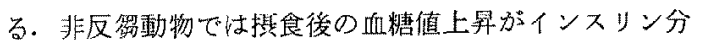

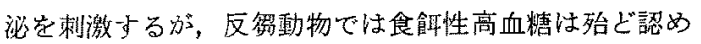
られない，浱厚飼料多給で血糖值の上显することはあっ

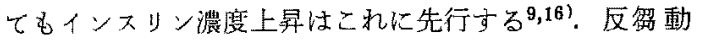
物では非反架勤物と異なって血糖值とインスリン濃度の 相関方低く8,16,21!，外因性ブドウ糖投与でインスリン分 泌の著增江認めるのだが，摆食後のインスリン分泌无進 に内因性血漿プドウ糖溇度の变動が関与する可能性は小 さい。

MANNS and BODA 22 はプロビオン酸扝よび酪酸の静脈 投与でめえ羊血奬インスリン演度が著しく上昇すること を見出した。，关の後この事実は多くの研究者に上り追認 され、13,16,18,23)，酢酸のインスリン分泌刺激作用は微弱で あることも明かにされた。吉草酸も強い刺激作用をも 24).これらの酸の作用がラット，家完，ブタなどでは 認められないことから，この作用は反紹動物に特異的に

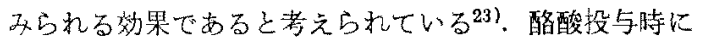
血糖值が高まるので，酪酸のインスリン分泌刺激作用が 高血糖を介する二次的勃果によるものではないかと疑わ れたが，in vitro の实験は酪酸の脺 $\mathrm{B}$ 細胞直接刺激作用 荬している ${ }^{25-27}$.

掑食後に第一胃内 VFA 生産が增加すること，および VFA がインスリン分泌制激作用在もつことから，摄食 後のインスリン分泌充進と VFAの関連についてさむざ まの議論焂かわさ机ている。乙の問題は, 生理的条件下

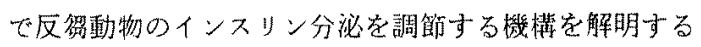
そいう難題ともからんで，研究者によって以下のような

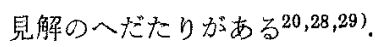

第一䨐壁から吸収されて閏脈に流入したブロピオン酸 および酪酸の殆ど全ては肝を一度通過するだけで除去さ れ30)，末梢血化出現する割合はきすめて小さい、いっぼ う，門脈血酶酸のかなりの部分は肝を通過して末梢血に 現われる、だが末梢血VFAの大部分苫占め吕酶酸のイ ンスリン分泌刺激作用は艌視し得るほぼ小さい23,31)。プ ロピオン酸，酪酸の静脈投与で，確かにインスリン分泌 が增加するが，关の場合これらの酸の血中濃度はお去ら

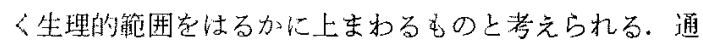

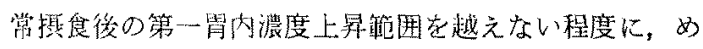
ん羊第一胃にVFA を投与するときインスリン分泌增 が認的られない13,32)。摄食後の末梢血 VFA 浱度, 酪酸

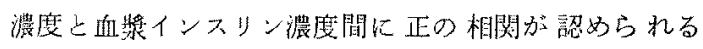

が9,18)，両煋の変化が単に平行しているということたけ では因果関係を証明することにはならない，ホルマリン 処理タンパク添加飼料では末処理のばあいより第一胃内 VFA 生産が低い化るかかわらずインスリン分泌法迹儿 高い19).これらの事実学举げて BASSETT20,28)，STERN

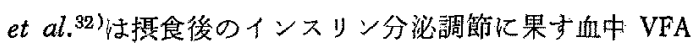
の効果について疑問定抱いている.

これに対して，絶食めえ羊第一胃に生理的濃度のVFA を注入するときインスリン分泌が認められる ${ }^{29)}$. 生理的 用量の VFA 門脈内投与でインスリン分泌增加するな どの証拠に基いて ${ }^{31}$ ， TRENKLE は，第一胃内 VFA 産生 增加が反架動物提食後のインスリン分泌調節に関与する と反論している.

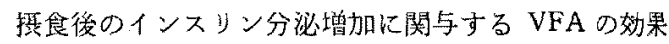
を完全に否定することはできないまでも，VFA のみが 関与すると考元ることる難しく，これ以外の調節因子の 関与を考慮する必要がある。

ヒト・イスなど非反羅動物でタンパク食愻食後にイン スリン分泌の高まることが知られている39).この分泌增 加の一部は血漿了ミ/酸浱度上昇によるものであり，他 はタンパク損食により分泌剌激をうけた消化管ホルモン のもつインスリン分泌刺激作用を介寸るものと考充られ ている33). めん羊でも高タンパク飼料給与時にインスリ ン分泌が高をり易い傾向にある8 $。$ めん羊のばあい摄食

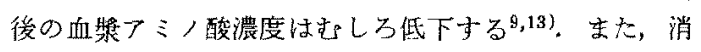
化管上り吸収されるフミノ酸の大部分はめん羊肝で除去 され，末梢血アミノ酸濃度は必ずしも吸収の程度家反咉 しない34! 各種フミノ酸の静㟲投与でインスリン分泌の 生ずることはめん羊でも認められているが16,24,35)，それ に要するてミノ酸投与量は生理的用量をはるかに越える ものであるので，掑食後のインスリン分泌增加を血嶈フ ミノ酸の変化から説明できるとは考党難い。

ELRICK et al. ${ }^{36}$ )拉よび MCINTYRE et al. ${ }^{37}$ は七トの耐 糖能検查比用いられるプドウ䌅静脈投与之経口投与客比 較し，経口投与でインスリン分泌の強いことを見出し た.この增強効果が，消化管内ブドウ糖に上り分泌刺激 される消化管ホルモンによるものであることが明らかに されて以来, 各種消化管木ルモンのインスリン分泌剌激 作用が注目されるようになった。ガストリン投与性ヒ卜 でインスリン分泌を刺激するが38，上卜食事後のインス リン濃度上㬤に関与する内因性ガストリンの効果は大き なむのでない99!テトラガストリン投与でめん羊インス

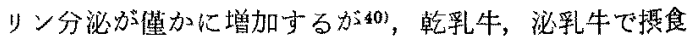
後の血漿ガストリン漲度に变化は認められず, 哺乳子牛

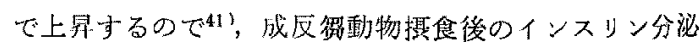




\section{没婜動物の膵内分泌}

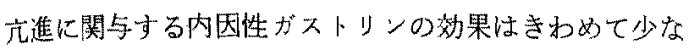
いものと考えられる. セクレチン投与でヒトのインスリ ン分泌が増加する ${ }^{42-45 !}$ ，行効果は高血糖で顕著にな る46). 山丰およびめ九羊ではセクレチンのインスリン分 泌刺激作用は殆ど認められないが40,47)，大舅投与で僅か

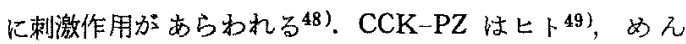
羊 ${ }^{40,48)}$ ，山羊 ${ }^{47}$ などでインスリン分泌を刺激する.CCK$\mathrm{PZ}$ 様生理活性をもつ decapeptide 七ルレインもイ 52，七ト53,54)，也九羊(作々末・末発表)，ラット55)せ1 ンスリン分泌刺激作用が認められる。 GIP (gastric in-

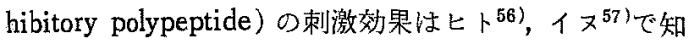
られているが，反微動物に関する報告は見当らない。粗 製 CCK-PZ 標品に GIP が混在し，GIP 抽出後の精製 $\mathrm{CCK}-\mathrm{PZ}$ にはインスリン分泌刺激作用が認められない という報告がある゙8). VIP (vasoactive intestinal polypeptide)のインスりン分泌に及代す勃果が非反䀜動物で 注目されているが59,60)，反解動物では，少くともめん羊 では，VIP 投与によって血獎インスリン浱度は上昇しな い40．VIP本来の作用が血流増加作用であるここからそ のinsulinotropic actionは少ないものと考えられている. 単独で投与寸るとき，殆どの消化管ホルモンのインス リン分泌能は弱く，加つ一過性である，文の作用は高血 糖やタンパク食提取時に強くあらわれる. 飼料拱取後の 消化管ホルモン分泌動態は，反雉動物では殆ど明かにさ

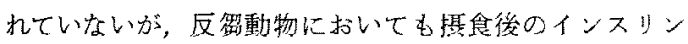

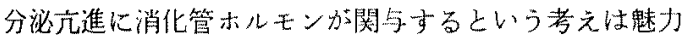
的であり，特に，繒の共存志必要とすることなしにイン スリン分泌を促進する唯一の消化管ホルモンである $\mathrm{CCK}-\mathrm{P} Z^{61)}$ の役割を今後明らかにする必要があるもの と考えられる。

成めん羊执よび仔めん羊の掑食開始 5 分以内に一過性

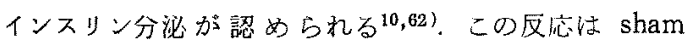
feeding わえ羊でも钼察される(10)。 た，ブドウ糖刺 激インスリン分泌子提食時後半よりす掑食值後で高い 68,64). フトロピン処理仔めん羊で㤌一過性分泌が消失す るので20)，この反応㨽交感神経を介する反射経路を経 るものと考えられる。同様の応答反応がイスでむ䑾認さ れている65,66)。島B細胞に副交感神経の分在すること は非反繁動物でよく知られており 67 ，迷起神経電気的刺

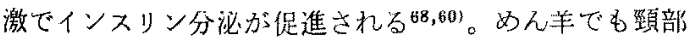
迷走神経切断で血墏インスリン濃度が低下し，时断遠心 端刺激で上昇与る70)。

めん羊のインスリン分泌量は $8.7 \mathrm{mU} / \mathrm{kg} \cdot \mathrm{hr}$ で る ${ }^{71}$. この值性反微動物の $12 \sim 18 \mathrm{mU} / \mathrm{kg} \cdot \mathrm{hr}$ より 加なり低い，絶食めん羊ではさらに分泌量が低下する
$(3.4 \mathrm{mU} / \mathrm{kg} \cdot \mathrm{hr})$.

\section{グルカゴン}

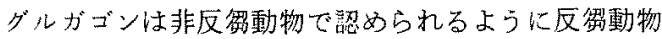
においても，肝よりのブドウ糖放出它促進しで冝糖上上 昇させる作用をもっている71,72)，この作用はフロキサン 糖尿め九羊で㩆著にあらわれる ${ }^{73}$. めん羊䀒からのブド ウ糖放出はグルカゴンのグリコーゲン分解招よび糖新生

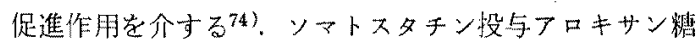

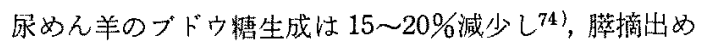
え羊よりるアロキサン糖尿めん羊で高血糖, 糖尿, タン パ分解が著しい75)，めん羊肝におけるダルカゴンの糖 新生促進は, 糖新生経路の key enzyme, pyruvate carboxylase の活性化どラニン，グルタミンなど䌅新生基 質とりこみの增加によるすのである73). 酪酸, プロピオ ン酸かららの精新生むグルカゴンによって促准される73, 77)。ウシ䀒スライスに打けるピルピン酸からの糖新生が dibutyryl cAMPによって促進されることからすると， ダルカゴンの作用は反繁動物でもおてらく adneyl cyclase 系を介するものと考えられる年．グルカゴンのプロ ピオン酸からの糖新生促進効果は in vitro でも確かめら れてい:名79,80).

グルカゴン連続注入によりめん羊血射遊離脂肪酸源度 が “過性に上昇したのち低下する ${ }^{72}$ ）－過性上昇はダル カゴンの脂肪酸動員真接作用によるまのであり，その後 の低下はグルカゴンにより分泌されたインスりンの脂筫 分解抑制作用によるものである。寒玲曝露めん羊ではイ ンスリン分泌が著しく抑制されており，ダルカゴンによ る脂肪酸動員が強くあらわれる81).インスリン分泌を抑

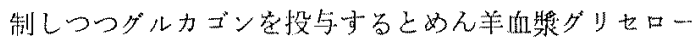
ルが増加する73,82). in vivo ではダルカゴンの脂肪分解 が認められるが，反贸動物の in vitroでの実駼結果はダ ルカゴンの脂質分解促進作用老認めてい等い83).

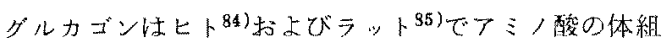

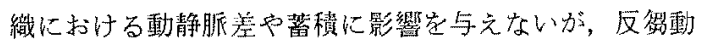

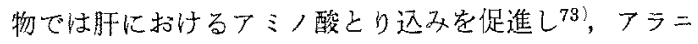

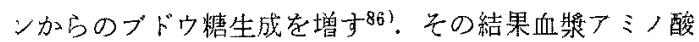
加低下し未梢組織へのアミ，酸供給が㺂少するものと考 えられる。

めん年倿よりのグルカゴン分泌量は $5 \sim 7 / \mathrm{g} / \mathrm{hr}$ で, インスリンの $1 / 2 \sim 1 / 3$ に相当す方 ${ }^{87}$ !

高血糖はめん羊膵ダルカゴン分泌を提制し，低血糖む゙

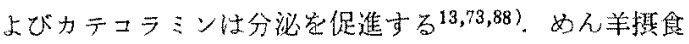

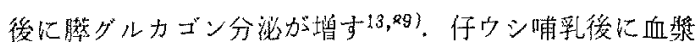
ダルカブン濃度が上是する90).ダルカゴンは旰よりのブ 
ドウ精放出を高める作用をもつが，掑食後にインスリン 分泌む同㭙に高まるので, 肝に達する雨ホルモン比は忹 ぼ一定であり，提食後の肝ブドウ糖放出の恒常性が維持 される20). 実験的 VFA 投与でめん羊および山羊のグル カゴン分泌が堌加する13,88,91). 力ゼイン水解物， 丁ミ， 酸混合被の第四胃注入，アミノ酸静脈投与でグルカエ゙ン 分泌が增す88,91,92). 膵グルカゴン測定の難しさもあっ て，反繁動物に打ける分泌動態はインスリン，成長ホル モンほど研究が進えでいない。

1966 年 UNGER et al. Kよって大量の GLI (glucagon like immunoreactivity) が膵以外に腸管にも存在するこ とが明らかに交った。このものは enteroglucagon, gut glucagon, gut type glucagon なよ゙さまざまの名称であ らわされているが, ラジオイムノケッせイてよるダルカ ゴンの概念を整理するため, 以下のような名称の続一が 提唱されている。膵より抽出したダルカゴン抢よび腸管 抽出物のグルカゴン分画の双方に交文反店を示守抗体で 測定される GLI t Total GLI と㭔び，脺グルカゴンに

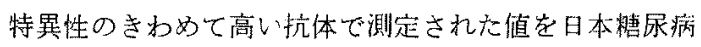
学会では GI (glucagon immunoreactivity), 国際的には IRG と㭔ぶ。 Total GLI 加ら GI あるいは IRG 差差引 Wた值を GLI 之呼ふ。.

BERZINS ${ }^{93)}$ は殼類多給でめん羊，ウシの血獎To・ tal GLI が增すが，IRG 浱度は粗飼料給与洔とはぼ同 レベルであることから，教類多給によって GLI が增加 することを皸告している。十二指腸内ブドウ糖投与で Total GLI が增し，IRG が低下する.7ミノ酸投与では Total GLI および IRG が増加するので, GLI 放出に消 化管内ブドウ精の関与することが示唆される。

\section{Energy partition とインスリン分泌}

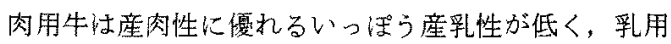
牛の産乳性はきわ枯高い，肉用牛は飼料エネルギーを

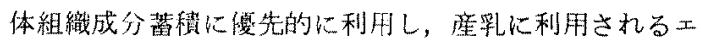
ネルキーは少ない，刘照的に，乳用牛の年間䎵乳量は $5,000 \mathrm{~kg}$ に達L，最大泌乳時には日量 $30 \mathrm{~kg}$ に達する。

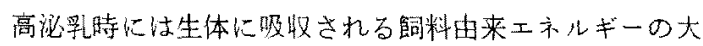

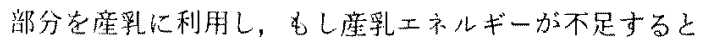

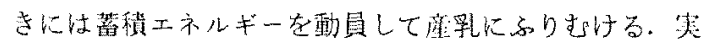

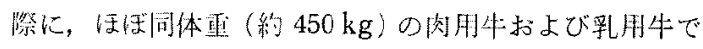

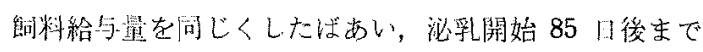
に，肉用牛は体重 $44 \mathrm{~kg}$ 增加しつつ $518 \mathrm{~kg}$ 安産乳し，

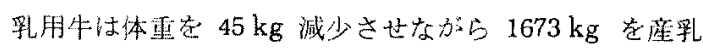

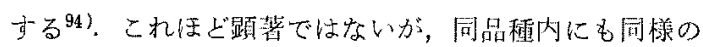
傾向のあることが認められて和り，低泌浮牛では泌乳閔
始 67 日後生での堌体重 $39 \mathrm{~kg}$, 産乳量 $837 \mathrm{~kg}$ てあるの に対して, 高泌乳牛では体重减 $52 \mathrm{~kg}$, 産乳量 $1352 \mathrm{~kg}$ であったと報告されている活，品種間あるいは品種内に 認められるこのようなエネルギー利用方向性の差翼性， 元来遭伝的に決定され多ものと理解できるが, energy partitionの調節に䡚々の内分泌機能の関与することは 疑いない，反够動物では，主として泌乳牛について energy partion と内分泌諸機能の閔連について研究が進め られて赫り，エネルギー利用方向性の調節飞成長ホルモ ン，甲状腺ホルモンなどとともにインスリンの関与す ることが知られている。

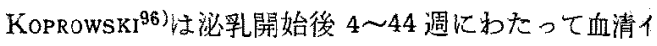
ンスリン湍度の推移を追跡し，汹乳量の減少とともに徐 々にではあるがその裖度が $20 \mathrm{uU} / \mathrm{ml}$ がら $100 \mathrm{uU} / \mathrm{ml}$ に 著增することを明らかにした。この事実はその後の報告 によって追認され，さらに，分婏後 $2 \sim 4$ 週の最大泌乳 時に血獎インスリンレベルが最も低下し, 以後, 泌乳量 の低下にともなって上昇することが確認されだ,98). 同 個体におけるこのような変化に加えて，高泌乳牛の血獎 インスリン濃度は泌乳期全体进通して低泌乳牛より持続

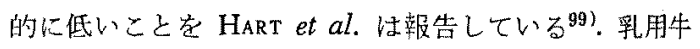
の血嫘インスリン濃度日内变動は肉用牛のそれと明らか に基なっている，血墏インスリンレベルは乳用牛で一 般に低く，日内変動に元しいが，肉用牛ではインズリ ンレベルが高く琵食後のインスリン分泌九進が著し い100).プドウ鈢，プロビオン酸投与によるインスリン分 泌尣進は泌秏中できわめて低く，乾乳牛で高い101,108). 泌乳中の乳用牛の血漿遊離脂肪酸濃度注同様の肉用牛よ り简い，乙冯は，脂質合成促進，分解抑制作用女すつイ ンスリンの分泌が乳用牛で低く，肉用牛で高いためと説 明される99)。また，インスリンはアミノ酸のタンパクの とり込みを促進し，タンパク分解を㧕制するなど，同化 作用促進ホルモンであること考慮す扎壮，肉用牛，乾 乳牛での分泌が高く泌乳中の期牛で最も低いことは energy partition の面から外てきいめて合目的的である と考えられる.膵よりのインスリン分泌量は泌乳牛で乾 乳牛の約 30\%に低下して招り，いっぱう朋でのインス リン除去率は泌乳牛で 60\%，乾乳牛で 85\%と報告され

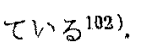

外因性インスリン投与は，抢てらく秏腺での脂肪酸と

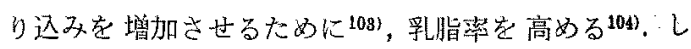
かし，通常飼育条件下に括ける内因性インスリンの航脂 肪染におよぼす影繁に閣しては别の説明が与えられてい る.一般に濃原餇籼多給下にある泌乳牛では，血糖およ びインスリンレベルが高まる。ブドウ糖およびインスリ 


\section{反帹動物の膵内分沘}

ンは脂肪組織の lipoprotein lipase 活性を高如て，脂肪 組織への脂肪酸とり远み增し脂翼合成を促進する。 そ のため，乳楿への脂肪酸供給が低下し，乳脂率が低下す $3^{(05)}$. 同一飼料条件下で低泌乳牛乳脂率の低いこと定説

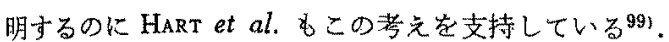

低泌乳牛乳腺に出けるブドウ楉消費仕高泌乳牛に比較 して低いにもかかかららず，飼料条件が同じであれば雨者 の血糖值はほぼ等しい99)。低泌乳牛ではインスリンレベ ルが高いため肝，筋，脂肪組織のブドウ糖利用が促進さ れるなど，乳腺以外の組織におけるブドウ消費が高泌䟭 牛より高いものと考えられる. インスリン投与によって 乳量が低下するが，ブドウ糖を投与すれば乳量は回復す 每108, 107)

乳腺で消費されるブドウ楉の起原は肝における精新生 に求められる.グルカゴンは反忽動物朋における榶新生 を促進するか゚，乳腺のブドウ結要求が最高に達し，肝で の糖新生量が増加しなければならない最大泌乳時のめん 羊肝細胞のダルカゴン結合能任乾乳時よりむしろ低下 し，泌乳の進行とともにグルカゴンおよびインスリン結 合能が高主る94. グルカゴンおよびインスリンの作用は 標的細胞膜ホルモンりセブターとの結合から始をるが， 反独動物組織におけるこれらホルモンの動向は不明の点 が多く，今後，種々の点で独特の代㖣特性をる つ反忽動 物の諸組織細胞膜り七プターの性質を明らかにする必要 がある乎のと考光られる。

$$
\text { ケトーシスとインスリン分泌 }
$$

反虫動物のケトーシスは生産病とも云古る代謝病の一 つである. primary spontaneous ketosis と呼ばれる釈牛 のケトーシスは分婏後 $3 \sim 8$ 週の高泌乳牛に多発し， pregnancy toxamia と㭔ばれるめん羊のケトーシスは妊 娠末期の多胎め九羊に発生し易い、いすを高ケトン 血，低血糖，食欲減退をともなう。高榄乳牛の乳腺で乳 糖括よび脂肪合成に必要なプドウ糖は莫大な量に達す光

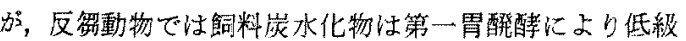
脂肪酸に転換するので，消化管由来のブドウ糖供給によ

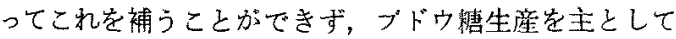
肝に怙けるプロピオン酸，厂ミノ酸などの前駆体からの 楆新生に頼らねばならない，糖新生により生成されるブ ドゥ粕量定越えて乳腺でのブドウ䌅消費が大になる

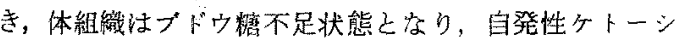
スでは一般に低血糖を是する108-111)。釈腺のブドウ糖要 求を充たすべく糖新生が增すとき；年の中間代謝産物て あるオギザロ酢酸が TCAサイタル定離れて粮新生に立 わるために，TCA サイクルのエネルギ一生成が低下し，
これを䋠らため朋における TCAサイクル以外の系にお ける酸化，すなわち，脂肪酸からケトン体への酸化が増 寸108). いっぽら体脂肪の分解が高まって, 低血桾と同時 に血永遊離脂肪酸が堌加し，ケトン体濃度が上昇する112114)。タトーシスの生化学，内分泌，于游，治療などに関 する議諭については他のすぐれた䊽説它参照された ฟ108-111,115-119).

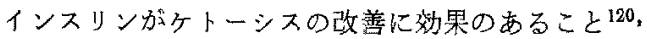
121)，拉よびインスリンがケトーシス発現を助長すること が，箺驗小動物について以前加ら知られている

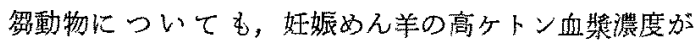
インスリンにより低下すること定 REID が報告し125)，反 劭動物ケトーシスとインスリン分泌の関連が注目される

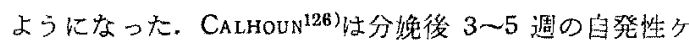
トーシスと健常牛を比較し，ヶトーシス牛で血獎インス リンベルの低下していること定 1962 年に始めて報告し た、CALHOUN はこの低下が低血糖にもとつく二次的現象 であり，インスリン加ケトーシス発現の直接原因とはな らないものと推論している. 翌年, KRONFELD は三頭の ケトーシス牛で $72,221,374 \mathrm{uU} / \mathrm{m} /$ のきわめて高い盘 獎インスリン搌度を顊察し，他の内分泌ホルモンととも にインスリンの hyper secretionるタトーシス発現の引 き金になり得ること党示唆した118)。しかし，この hyperinsulinism がタトーシスのどの時期に観察されたむの であるのか明記されなかった，その後 1971 に至って，

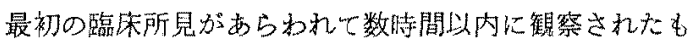
のであったことを明らかにし，臨床所見ではヶトーシ

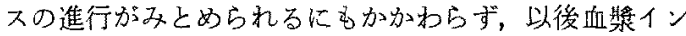

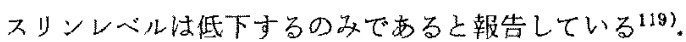
KRONFELD によれば，ケトーシス発兒と内分泌䒺のかか わりはき蚁複雑なるのであるが，もしインスリンの 関与することがあるとすればごく短特間内に生ずる一過 性インスリン分泌圥淮によって低血磄がはじまり，続い てインスリン分必低下があることになる。

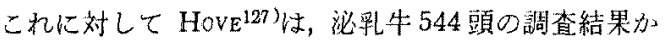
ら，血獎インスリン濃度の原因となるような hyperinsulinism は認められないことを報告し，KRONFELD の仮 説性あくまで間接的なものであって策証性に之しいと反

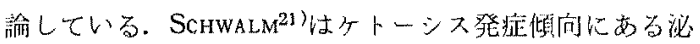

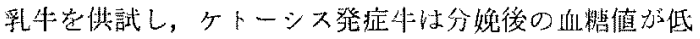

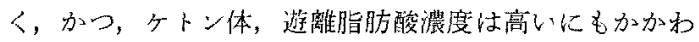
らず，分婏後の血俆インスリンレベル低下の程度は発症 牛，非発症牛で変らないこ之を認めている. KRONFELDも 䢞べているように1199，彼の仮説を实証することはかな り困難のようである。現在までケトーシス登症の一因と 
なるような hyperinsulinism は彼自身の観察した三例以 外は見つかっていない，他はすべてケトーシスでインス リン分泌の低下を報管したものばかりである。ケトーシ ス牛では，ブドウ糖に刘するインスリン分泌反応も弱 く，拈食後のインスリン分泌克進も著しく抑制されてい $\zeta^{128,129)}$.

前項で述べたように，高泌乳牛ではインスリンンべル が低く，低泌乳牛で高い。ケトーシスは高泌乳牛で発症 し易いので，インスリンレベルも一般に低い傾向にあ る.自発性ケトーシスのインスリンレベル炭論じると き，特にこの点に注目する必要があるものと思われる。 実際問題として，ケトーシス牛と同泌釈量の対照動物定 求めるのは困難なことであるが，乳量の低い動物を対照 にして比較す机ば，彭视乳ケトーシス牛のインスリンレ ベルは常に低いことになるのである。この点で, 前記 SCHWALM の竍告では刘照牛の乳量はケトーシス牛と同 じであり，てして、ケトーシス牛におけるインスリンし ベル低下は対照牛之同等である21!。

いずれにしろ，高泌乳ケトーシス牛でインスリン分泌 の低下することは事実である，そのため末梢のインスリ ン感受性をもつ組織でのブドウ楉および酩酸の利用は东 寸主低下し，脂肪酸動員がより活潑になり，肝でのヶ トン体生成孔增加する、ラッテ乳腺のブドウ糖とり込み

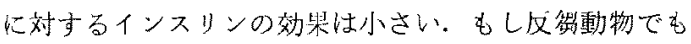
そうであるとすると，ケトーシスでインスリン分祕が低 下しても乳腺でのブドウ糖利用は低下世ず，乳腺以外の 組織のプド不足はさららに染剆になるものと考元られ る.

MANNS $^{131}$ 灶正常牛の分婏後に GLI の上昇によるもの と推測できるTotal GLI の著增を報告し，グルカゴンに よる脂肪酸動具もケトン休濃度を高码可能性のあるこ とを指摘している.

\section{環境温と膵内分泌}

寒冷瑨境での神経系抢よひ内分泌系の機能に関する研 笕はこれをで主として，カテコラミン，甲状腺ホルモ ソ，副腎皮質ホルモンなど，産熱基質動員を促進して熱 生産高內異化作用促進ホルモンの分泌動態に注意が 払わ机てきた。同化作用促進木ルモン，インスリンの分 泌動態については2，3の跟告を除けば多んじ知られて いない。

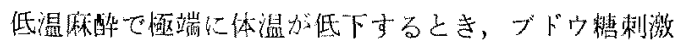
インスリン分泌の低下することが，七ト，イメ，新生 ットで知られている(132-137)。このときアドレナリン作動 性 $\alpha$ 受容体をマスクナると分泌抑制方緩和されることか
ら，低体温でのインスリン分泌抑制はカテュラミンによ る阻害作用で生ずるすのと考光られた。 これ対して, CURY et al.138)は, in vitro で膵の培養温度を低下させる とインスリン分泌が著減すること若えれば，低体温の むたらすB細胞のインスリン分䟤㨁接抑制效果老無視し 得ない己指摘した。

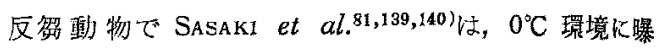
露した正常体温煎毛め儿羊のブドウ糖刺激インスリン分 泌が著しく抑制されることを明らかにしている。この抑 制はフドレナリン作動性 $\alpha$ 受容体阻害削フェントラミン の投与で解除される. また，寒冷曝露めん羊でフェント ラミン投与は血漿インスリン基濋分泌レベル高める が，常温環境では変化がない，さらに，寒冷時にアドレ ナリン，ルアドレナリンのめん羊尿への排莇方增加す $ろ^{141)}$.これらの事寒は寒冷環境で緊張しためん羊交感神 経副腎髄質系が, 膵ラ島 B 細胞アドレナリン作動性 $\alpha$ 受 容体を介してインスリン分泌它抑制すること定示唆して いる.酪酸，ダルカゴン，トルプタマイド制激インスリ ン分泌反㦄子寒冷曝露內九羊で抑制されている81,1899. た，1〜18 日歯命仔め九羊の $-5 \sim-15^{\circ} \mathrm{C}$ 環境，40 分曝露 で低体温となり血漿インスリン浱度が低下する ${ }^{142}$.成め ん羊を $1^{\circ} \mathrm{C}$ 謤境に曝露して掑食させるときインスリン分 泌克進がみられる143).

KAMAL et al. は乾乳牛の $32^{\circ} \mathrm{C} 3$ 日旿露で血墏インス

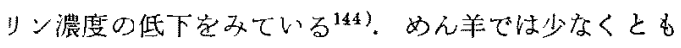
$30^{\circ} \mathrm{C} ， 10$ 日曝露でプドウ糖によるインスリン分泌反応に 党混との有意差は認如られず，耐糖能が若干低下する (佐々朴・米発表).

Bloom et al.145,146) はめえ羊および子ウシ内贜神経切 断遠心端電気的刺激で IGR の高をることから，生体に 加わるストレスによって交感神経采吕緊張すれば，ダル カゴン分泌が充進するものと推諭し，ダルカゴンをスト レスホルモンの一つに数えている. 寒冷曝露めん羊に種 種の刺激物質を投与するとき，IGR 分泌は刺激物貿の 種類によって常温より高く西るいは低くあらわれること

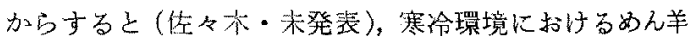
グルカゴン分泌はかなり複雑な調節機棈の下纪営な立れ ているものと考えられる。寒冷曝露でラットの血獎 IRG 濃度は上景し，暑熱で低下する ${ }^{147,148)}$ 。

\section{B 細胞のインスリン分泌機棈}

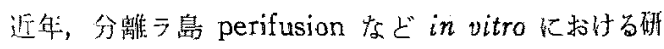
究の発展に支えられて，非反虫動物膵B細胞のインスリ ン分泌機桠が解明され秃つある。いっぽう反繁動物では 上䓃成綃が全て in vivoで得られたものであるだけに， 
複雑に交錯する血中代謝物筫，神経系，内分泌系など諸 要因の影響を排除することができず，B細胞インスリン 分泌機棈の解析が著しく逑九ていたが，最近に至り，in vitro での研究に関して 2,3 の諭文が発表された。 その

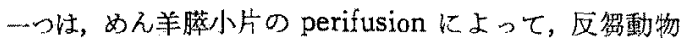
膡上りのインスリン分汹動的ハターンをはじめて明らか にしたもので ${ }^{25,26)}$ ，他はめえ羊薪加らのラ島分離を成功 させてその static incubation 学行ったものである27).

めん差膵のブドウ楉刺激インスリン分泌反応性刺激初 期火7られる一過性の鋭以分泌相と, それk続く低レー いの第二の分泌相から成る.ブドウ糖刺激インスリン分 泌が二相性であることは perfusion あるいは perifusion

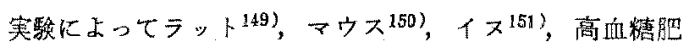

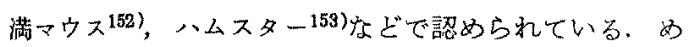
ん羊で諗められる二相性はこれら単青動物を基本的に一 致するが，二相性を得るのに phosphodiesterase 阻害剂 芯必要とする点で成ラットと異なっており，むしるラッ 卜胎仔膵に近い154)。このこ死はん羊B細胞で phosphodiesterase 活性が高いことを示唆するものかもしれ ないめえ羊で得られるインスリン分泌第二相のレベル 甠，ラット149)、、ウスなどの ${ }^{150)}$ ，第一相のレヘルをは

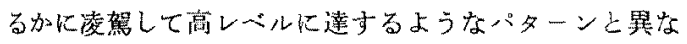
り，かなり低いいびルある、めん羊のインスリン分泌 第二相蛙，この点で八ムスター155,156), 家鬼に近い.

ブドウ䌅刺激インスリン分泌の引き金となるのは細胞 内 $\mathrm{Ca}^{++}$濃度の上昇之考えられている.ブドウ糖刺激に よって細胞内への $\mathrm{Ca}^{++}$流入が增(158), 流出が減少す

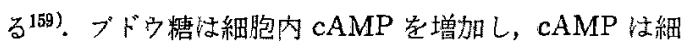
胞内貯蔵プールがら $\mathrm{Ca}^{++}$遊離觉促進する ${ }^{160}$. 細胞内 $\mathrm{Ca}^{++}$濃度が上昇すると，微小線維構造が，あたかも筋 肉細胞收縮タンパクが収縮するようにらぢまり， 細胞膜方向に運搬し開口分泌他至る161）。九羊脺小 片に Ca free の条件下でブドウ糖刺激を加える上，イン スリン分泌第二相が消失し第一相の多現われる 条件下の酪酸刺激では再相が消失し，インスリン分泌が 生じない，叔そらく，酪酸刺激インスリン分泌細胞外 Ca が不可欠なのであるう。ブドウ糖和よび酪酸が反劦 動物インスリン分泌の直接刺激物質であることもこれら の事実がら明らかである。

JORDAN and PHILLIPS ${ }^{27)}$ はめん羊脺より分離したラ島

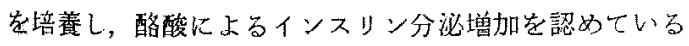
が，酪酸刺激でA細胞から放出されるグルカゴンがイン スリン分沙炭さらに高める可能性がある。

酪酸刺激によるインスリン分泌 dynamic response は めえ羊を除いて他の動物では全く知られていない25)。酪
酸制激インスリン分泌は二相性であるが，ブドウ糖制激 時に比較して第二相のレベルが高い。このことは, in vivoで酪酸定投与するとき，ブドウ蓎投与時よりるイン スリン分泌反灾の強いこととよく一致する。細䑦レベル および生体レベルでの膵内分泌調節機棈の詳細について は多数のすぐれた総說參参照されたい6!-170).

\section{文献}

1) Rerd, R. L., Aust. J. Agric. Res., 2: 132-145. 1951.

2) ReID, R. L., J. Endocr., 27: 1-9. 1963.

3) Jarrett, I. G., O. H. Filsell and F. J. Ballard, Horm. Metab. Res., Suppl. 4: 111, 1972.

4) Skarda, J. and S. Bartoo, J. Endocr., 44: 115119. 1969.

5) YAng, Y.T. and R.L. Baldwin, J. Dairy Sci., 56: 350-365, 1973.

6) Mears, J. G. and V. E. Mendel, J. Physiol. 240, 625-637. 1974.

7) Yallow, R.S. and S. A. Berson, J. Clin. Invest., 39: 1157-1175. 1960.

8) Bassett, J.M., R. H. Weston and J.P.Hogan, Aust. J. Biol. Sci., 24: 321-330. 1971.

9) Bassett, J.M., Aust. J. Biol. Sci., 27: 167181. 1974.

10) Bassett, J.M., Aust. J. Biol. Sci., 27: 157166. 1974.

11) McAtee, J.W. and A. Trenkle, J. Anim. Sci., 33: 612-616. 1971.

12) Bassett, J.M. and A. L.C. Wallace, Diabtes, 16: 566-571. 1967.

13) Bassett, J. M., Aust. J. Biol. Sci., 25: $1277-$ 1287. 1972 .

14) Hove, T. and A. K. Blom, Acta. Endocr, 73: 289-303. 1973.

15) Lofgren; P.A. and R.G. Warner, J. Anim. Sci., 35: 1239-1247. 1972.

16) McAtee, J.W. and A. Trenkle, J. Anim. Sci., 33: 438-442. 1971.

17) Ross, J.P. and W. D. Kitts, J. Nutr., 103 : 488-493. 1973.

18) Trenkle, A., J. Nutr., 100: 1323-1330, 1970.

19) Faichney, G. T. and R. H. Weston, Aust. J. Agr. Res., 22: 461-468. 1971.

20) Bassett, J.M., Digestion and Metabolism in the Rumiant. (McDonald, I. W. and A.C.I. Warner, eds) 383-398. Univ. New England Pub. Unit. Armidale, 1974.

21) Sbhwalm, J.W. and L. H. Schultz, J. Dairy Sci., 59: 255-261. 1976.

22) Manns, J. G. and J. M. Boda, Am. J. Physiol, 212: 747-755. 1967.

23) Horino, M.L., J. Machlin, F. Hertelendy and D. M. Kipnis, Endocrinology, 83: 118-128. 
1968.

24) Hertelendy, F., L. Machlin and D. M. Kipnis, Endocrinology, 84: 192-199. 1969.

25) SASAKI, Y., T.E.C. Weekes and J.B. Bruce, J. Endocr., 72: 415-416, 1977.

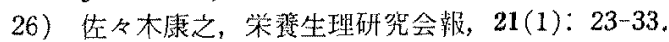
1977.

27) Jordan, H. N. and R.W. Phildips, Am. J. Physiol., 234: E162-E167. 1978.

28) Bassetr, J. M., Proc. Nutr. Soc, 37:273-280. 1978.

29) Trenkle, A., J. Dairy Sci., 61: 281-293. 1978.

30) Bergman, E. N. and J. E. Wolf, Am. J. Physiol., 221: 586-592. 1971.

31) Manis, J.G., J. M. Boda and R. F. Willes, Am. J. Physiol., 212: 756-764. 1967.

32) Stern, J. S., C. A. Balle and J. Maner, Am. J. Physiol., 219: 84-91. 1970.

33) Fajans, S. S. and J.C. Floyd, Handbook of Physiology section $7 \mathrm{Vol}$. I. 473-493. Amer. Physiol. Soc., Washington, 1972.

34) Wolf, J.E., E. N. Bergman and H. H. Williams, Am. J. Physiol,, 223: 438-446. 1972.

35) Davis, S. L., Endocrinology, 91:549-555. 1972.

36) Elrick, H., L. Stimmler, C. T. Hlad, Jr. and Y. Arai, J. Clin. Endocr., 24: 1076-1082. 1963.

37) McIntyre, N., C.D. Holosworth and D. S. TURNer, Lancet, II, 20-21. 1964.

38) Rehfeld, J.F. and F. Stadir, J. Clin. Invest., 52: 1415-1426. 1973.

39) Hayes, J.R., J.ARdil. and K. D. Buchanan, Diabetologia, 11: 89-92. 1975.

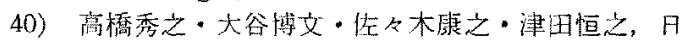
音学会第 69 会大会講演要旨, 91，1979.

41)安田和雄, 栄鉒生理研究会韩, 22(1): 1-13. 1978.

42) Enk, B., B. Lund, A. Schmidt and T. Deckert, Acta Endocr., 82: 306-311. 1976.

43) Enk, B., Acta Endocr., 82: 312-317, 1976.

44) Lerner, R. L, and D. Porte, Jr., J. Clin. Invest., 51: 2205-2210. 1972.

45) Chisholm, D. J., J.D. Young and L. Lazarus, J. Clin. Invest., 48: 1453-1461. 1969.

46) Shima, K. and S. Tarul, Endocr. Japonica, 21: 13-18. 1974.

47) Baile, C. A., Z. Glick and J. Manep, J. Dair Sci., 52: 513-517. 1969.

48) TRENKLE, A., J. Dairy Sci, 55: 1200-1211. 1972.

49) Dupre, J., J. D. Curtis, R. H. Unger, R. W. WAdDEL and J.C. Beck, J. Clin. Invest., 48: 745-757. 1969.

50) De Caro, G., G. Importa and P. Melchiorri, Experimentia, 26: 1145-1446, 1970.

51) Bertaccini, G., G. De Caro and P. MelchiorRI, Br. J. Parmac., 40: 78-85. 1970.
52) Ohneda, A., K. Hocigome, S. Ishil, Y. Kal and M. Chiba, Horm. Metab. Res, 10: 7-11. 1978.

53) Falluca, F., R. Carratu, G. Tamburrano, M. Javicoli and G. Menzinger, Folia Endocr., 22; 524-529. 1969.

54) Falluca, F., R. Carratu, G. Tamburrano, M. Javicoli, G. Menzinger and D. Andreani, Horm. Metab. Res., 4: 55. 1972.

55) Otsuki, M., C. Sakamoto, M. Maeda, H. Yuu, S. Morita and S. BABA, Endocrinology, 105: 1396-1399. 1979.

56) Dupeer, J., S. A. Ross, D. Watson and J.C. Brown, J. Clin. Endocr. Metab., 37: 826-828. 1973.

57) Penerson, R. A., H. E. Schubert and J. C. Brown, Can J. Physiol. Pharmac, 53: 217223. 1975.

58) Rabinovitch, A. and J. Dupere, Endocrinology 94: 1139-1144. 1974.

59) Schebalin, M., S.I. Said and G. M. Makhlouf, Am. J. Physio!., 232: E197-E200. 1977.

60) Kaneto, A., T. Kaneto, H. Kajinuma and K. KosaKA, Metabolism, 26: 781-786. 1977.

61) Schatz, H. J. Otto, M. Hninz, V. Maier, C. Nierle and E. F. Pfeiffer, Endocrinology, 94: 248-253. 1974.

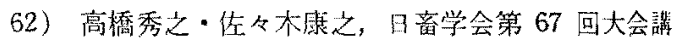
演䣶旨, 106, 1977.

63）传々本康之・高橋秀之 - 彦坂和雄 - 麻生 久, 日 畜学会第 69 回大会講演要旨, 92, 1979.

64) Hikosaka, K., Y. SASAKI and T. Tsuda, Ann, Rech. Vet., 10: 237-239. 1979.

65) Fischer, U., H. Hommel, M.Ziegler and R. Michael, Diabetologia, 8: 104-110. 1972.

66) Hommel, H., U. Fischer, K. RetzlafF and $\mathbf{H}$. KNOFLER, Diabetologia, 8: 111-116. 1972.

67) Lacy, P.E. and M. H. Greider, Handbook of Physiology section 7 Vol. I. 77-89. Amer, Physiol. Soc., Washington, 1972.

68) Kaneto, A., K. Kosaka and K. Nakao, Endocrinology, 80: 530-536. 1967.

69) Frohman, L. A., E. Z. Ezdinli and R. Javid, Diabetes, 16: 443-448. 1967.

70) 高橋秀之, 東北大学学位論文, 1975.

71) Brockman, R.P. and E. N. Bergman, Am. J. Physiol, 229: 1338-1343.

72) Bassett, J.M., Aust. J. Biol. Sci., 24; 311320. 1971.

73) Brockman, R. P., E. N. Bergman, P. K. Joo and J. G. Manns, Am. J. Physiol,, 229: 1344-1350. 1975.

74) Brockman, R. P. and M. R. Johnson, Can. J. Anim. Sci., 57: 177-180. 1977.

75) Jarrett, I. G., Progress in Endocrinology (Gual, G. and F. J. G. Ebling, eds.) 176. Experta Met. 


\section{稳動物の脺内分论}

Int. Cong. Ser. 184, Amsterdam, 1969.

76) Brockman, R.P. and J. G. Manns, Cornell Vet., 64: 217-224, 1974.

77) Brockman, R. P., Fed. Proc., 37: 339. 1978.

78) Atwal, A.S. and F. Sauer, Int. J. Biochem., 4: 283-292. 1973.

79) Clark, M. G., O. H. Filsell and I. G. Jarrett, Biochem. J., 156: 671-680. 1976 .

80) Sayan, P.M. J., M.K. Jeacock and D. A. L. Shepherd, Proc. Nutr. Soc., 30A, 1976.

81）高橋秀之・侁々本康之，栄裳生理研 究会報，23 (1): 69-83. 1979.

82) Brockman, R. P., Can. J. Comp. Med,, 40: 166-170. 1976.

83) Bauman, D. E., Fed. Proc., 35: 2308-2313. 1976.

84) Pozefsky, T., R. G. TANCredi, R. T. Moxley, J. Dupre and J. D. TOBIN, Diabetes, 25: 128135. 1976.

85) Fuller, R. W. and J. C. Baker, FEBS Letters, 53: 8-9. 1975.

86) Brockman, R.P. and E. N. Bergman, Am. J. Physiol., 228: 1672-1633. 1975.

87) Brockman, R.P., J. G. Manns and E. N. BergMan, Can. J. Physiol. Pharmacol, 54: 666-670. 1976.

88) Arcus, A.C., M. J. Ellis, R. D. KIRK, D. W. Beavan, R, A. Donald, D. S. Hart, G. W. Hol land and C. Redekopp, Aust. J. Biol. Sci., 29: 223. 1976.

89) Bergner, H. and R. Gorsch, R., Ann. Rech. Vet., 10: 382-384. 1979.

90) Bloom, S. R., A. N. Edwards, R. N. Nbrdy, K. W. Malinowska and M. Silver, J. Physiol., 253 135-155. 1975.

91) Bryce, D., M. Yeh, C. Funderburk, H. Todd and F. Hertelendy, Diabetes, 24: $842-850$. 1975.

92) Bassett, J. M., Ann. Rech. Vet, 8: 362-367. 1977.

93) Berzins, R. and J.G. Manns, J. Dairy Sci., 62: 1739-1745. 1979.

94) Bines, J. A. and I. C. Hart, Proc. Nutr. Soc., 37: 281-287. 1978.

95) Broster, W. H., V.J. Broster and T.SMith, J. Agr. Sci. Camb., 72: 229. 1969.

96) Koprowski, J.A. and H. A. Tucker, Endocrinology, 93: 645-651. 1973.

97) Jenny, B. F., C. E. Polan and F. W. Thye, J. Nutr., 104: 379-385. 1974.

98) Smith, R. D., W. Hansel and C. E. Coppock, J, Dairy Sci., 59: 248-254. 1976.

99) Hart, I. C., J, A. Bines, S. V. Morant and J. L. Ridley, J. Endocr., 77: 333-345. 1978.

100) Hart, I. C., J.A. Bines, C. C. Balch and A. T. Cowne, Life Sci., 16: 1285-1292. 1975.
101) Frobish, R. A. and C. L. Davis, J. Dairy Sci, 60: 204-209. 1977.

102) Lamax, M. M., G. D. Baird, C.B. Mallinson and H.W.Symonds, H.W., Biochem. J., 180: 281-289. 1979.

103) Marinez, D. I, C. A. Ricks and R. M. Cook, J. Agr. Food Chem., 24: 927-935. 1976.

104) Sснмidt, G.H., J. Dairy Sci., 49: 381-385. 1966.

105) Rao, D. H., G. E. Hawkins and Smith, R. C., J. Dairy Sci., 56: 1415-1419. 1973.

106) Kronfeld, D. S., G.P. Mayer, J. M.Robertson and F. RAGGI, J. Dairy Sci., 46: 559-563. 1963.

107) Linzell, J.L., J. Physiol., 190: 347-357. 1967.

108) KREBS, H. A., Vet. Rec., 78: 187-192, 1966.

109) Rerd, R. L., Adv. Vet. Sci., 12: 163-238. 1968.

110) Payne, J. M., Int. Rev. Exp. Pathol., 9: 191232. 1970.

111) Bergman, E. N., J. Dairy Sci., 54: 936-948. 1971.

112) Radolf, H. D. and L. H. Schultz, J. Dairy Sci., 50: 68-72, 1967.

113) Schultz, L. H., J. Dairy Sci., 51: 1133-1140. 1968.

114) Schwalm, J. W. and L. H. Schultz, J. Dairy Sci., 56: 672. 1973.

115) Baird, G, D., R. J. Heitzman, K. G. Hibbitt and G. D. Hunter, Br. Vet. J., 130: 214-220. 1974.

116) Baird, G. D., R. J. Heitzman, K. G. Hibitt and G. D. Hunter, Br. Vet. J., 130: 318-326. 1974.

117) Baird, G. D., Biochem. Rev., 5: 819-827. 1977.

118) Kronfeld, D.S., Ann. New York Acad. Sci., 104: 799-817. 1963.

119) Kronfeld, D.S., J. Dairy Sci., 54: 949-961. 1971.

120) Bressler, R. and F. L. Engel, Proc. Soc. Exp. Biol. Med., 35: 738-741. 1957.

121) Amatruda, T. T., Jr. and F. L. Engel, Yale J. Biol. Med., 31: 303-323. 1959.

122) Scow, R. O. and S. S. Chernick, Recent Progr. Horm. Res., 16: 497-546. 1960.

123) Simon, E., R. O. Scow and S. S. Chernick, Am. J. Physiol., 201: 1073-1077. 1961.

124) Sweeney, M.J., Jr., R. Mahler and C. N. N. Long, Fed. Proc,, 21: 202. 1962.

125) Red, R. L., Aust. J. Dgr. Rest., 11: 530-538. 1960.

126) Calhoun, M. C., J. L. Fleeger and C. R. RichARDS, J. Dairy Sci., 45: 421-426, 1962.

127) Hove, T., Acta Endocr., 76: 513-524. 1974.

128) Hove, T., J. Dairy Sci., 61: 1407-1413, 1978,

129) Hove, T. and K. Halse, Acta. Vet. Scand., 19: 215-228, 1978.

130) Robinson, A. M. and D. H. Williamson, Bio- 
chem. J., 168: 465-474, 1977.

131) Manns, J. G., Can. Vet. J., 13: 151-155. . 1972.

132) Baum, D., D. H. Dillakd, H. Mohri and E. W. CraWford, Pediatrics, 42: 93-105. 1968.

133) Baum, D., D. H. Dillard and D. Porte, Jr., New Engl. J. Med., 279: 1309-1314. 1968.

134) Baum, D. and D. Porte, Jr., Am. J. Physiol., 221: 3U7-311. 1971.

135) Blackard, W. G., N. C. Nelson and J. A. Labat, Am. J. Physiol, 212: 1185-1187. 1967.

136) Kervran, A., M. Gilbert, J.R. Girard, R. Assan and A. Jost, Diabetes, 25: 1026-1030. 1976.

137) Lin, B. J., J. Hunter, R. Weldon and R. E. HaIst, Can. J. Physiol. Pharmac., 46: 411-415. 1968.

138) Curry, D. L. and K. P. Curry, Endocrinology, 87: 750-755, 1970.

139) Sasaki, Y., H. Takahashi and K. Hikosaka, Ann. Rech. Vet., 10: 388-390. 1979.

140) Sasaki, Y. and H. Takahashi, J. Physiol, (accepted, in press)

141) Sasaki, Y., S. Oshiro, M. Miura and T. Tsuda, Jpn. J. Zootech. Sci., 44: 222-231. 1973.

142) Bassett, J.M. and G. Alexander, Biol. Neonate, 17: 112-125. 1971 .

143) Thompson, G. E., J. M. Bassett and A. M. Bell, Brit. J. Nutr,, 39: 219-226. 1978.

144) Kamai, T.H., I.I. Ibrahm, S. M. Self and H. D. Johnson, J. Dairy Sci,, 53: 651. 1970.

145) Bloom, S. R., A. W. Edwards and N. J. A. VaugHAN, J. Physiol., 233: 457-466. 1973.

146) Bloom, S. R. and A. V. Edwards, J. Physiol,, 253: 157-173. 1975.

147) Kuroshima, A. and K. Dor, Experimentia, 32 : 473-474. 1976.

148) Kuroshima, A., K. Dor and T. Ohno, Life Sci., 23: 1405-1410. 1978.

149) Curry, D. L., L. L. Bennett and G. M. Grodsky, Endocrinology, 83: 572-584. 1968.

150) Cooper, R. H., S. J. H. Ashcroft and P.J. RaNDLE, Biochem. J., 134: 599-605. 1973.

151) Iversen, J., J. Clin. Invest., 52: 2102-2116. 1973.
152) Idahl, L. A., Diabetologia, 9: 403-412. 1973.

153) Frankel, B. J., J.E. Gerich, R. Harura, R. E. Fanska, G. C. Gerritsen and G. M. Grodsky, J. Clin. Invezt., 53: 1637-1646: 1974.

154) Lambert, E. A, Y. Kanazawa, I. M. Burr, L. Orci and A. E. Renold, Ann. New York Acad. Sci., 185: 232-244. 1971.

155) Curry, D. L., L. L. BennetT and C. H. Li, J. Endoci., 65: 245-251. 1975.

156) Gerhards, E. and M. Ruhl, Acta Endocr., 76; 302-318. 1974.

157) Garcia-Hermida, O. and J. Gomez-Acebo, Biochem. Biophys. Res. Comm., 57: 209-215. 1974.

158) Hellman, B., J. Sehlin and I.B. Taljedal, J. Physiol, 254: 639-656. 1976.

159) Malaisse, W. J., Israel J. Med. Sci., 8: 244251. 1972.

160) Brisson, G. R., F. Malaisse-Lagae and W.J. Malaisse, J. Clin. Invest., 51: 232-241. 1972.

161) Lacy, P.E. and W. J. Malaisse, Recent Progr. Horm. Res, 29: 199-228. 1973.

162) Gerich, J.E., M.A. Charles and G. M. GrodsKY, Annu. Rev. Physiol,, 38: 353-388. 1976.

163) Unger, R. H. and L. Orci, Physiol. Rev., 56: 778-826. 1976.

164) Sharp, G.W.G., C. Wolhem, W.A. Muller, A. Gutzeit, P. A. Trueheart, B. Blondel, L. Orci and A. E. Renold, Fed. Proc, 34: 15371548. 1975.

165) Woods, S. C. and D. Porte, Jr., Physiol. Rev., 54: 596-619. 1974.

166) Frohman, L. A., Annu. Rev. Physiol., 31:353382. 1969.

167) LAcy, P., Advances in Motabolic Disorders; 7: 171-182. 1974.

168) Grodsky, G. M., H. Sando, S. Levin, J. Gerich and J.KARAM, Advances in Motabolic Disorders, 7: 155-170. 1974.

169) Mayhew, D. A., P. H. Wright and J. Ashmore, Pharmac. Rev., 21: 183-212. 1969.

170) Porte, D., Jr. and J. D. Bagdade, Annu. Rev. Med., 21: 219-240. 1970. 